\title{
Matter-Theatre: Conspicuous Construction in Cymbeline
}

\author{
CALLAN DAVIES \\ University of Roehampton
}

[Part of a special issue of Shakespeare Bulletin that revisits the concept of metatheatre. Forthcoming, Vol. 36, Issue 1 (Spring 2018).]

Five times in Cymbeline, a character asks, "what's the matter?" (1.1.3). ${ }^{1}$ This question conspicuously opens up various meanings of "matter" in the play, and - in the context of this special issue - invites reflection on the role of "matter" in metatheatre. The question appears as early as the third line (fifth in the Folio), part of the exposition in which two gentlemen discuss Imogen's engagement. The term then continues to feature throughout the play, both explicitly, by verbal reference, as well as implicitly, by allusion, echo, and association. The word "matter" draws on both rhetoric and early modern "science" from technology to anatomy; it has resonance in early modern England through its legal applications (the subject to be tried or approved, for example, OED $n^{1} 13 a$ ) and scholastic terminology (as in Aristotelian theory, where it signifies the "component of a thing that has bare existence" that must be joined with "form," OED n $\left.{ }^{1} 22 a\right)$. Matter also has wider and more flexible understandings in this period, from its uses in logic as the contents of a given argument or contention (OED $\left.\mathrm{n}^{1} 24\right)$, as well as its broadest meaning of “thing, affair, concern" (OED $\left.n^{1} 1 \mathrm{a}\right)$. The slipperiness of the word in early modern discourse forms Hamlet's playful response to Polonius's enquiry about the content of what he is reading:

HAMLET: Words, words, words.

POLONIUS: What is the matter, my lord? 
HAMLET. Between who?

POL. I mean the matter that you read, my lord. (2.2.189-92)

Hamlet deliberately misunderstands matter to mean a contention, with its legal senses of something to be tried between two parties, rather than its rhetorical relationship to "words" as the subject of a book or speech (OED n $\left.{ }^{1} 9 a\right)$. Polonius's subsequent comment of Hamlet's toying, "there's method in it" (11.201-2), brings the meanings full circle to logic.

Matter is a major element in Cymbeline's self-conscious artifice and it places explicit emphasis on the rhetorical construction of Shakespeare's playworld and its narrative fragility. "Matter" serves as an historically-appropriate alternative to the twentieth-century coinage, "metatheatre," first used by Lionel Abel in 1960. As Sarah Dustagheer and Harry Newman observe in their introduction to this special issue, scholars of sixteenth- and seventeenth-century drama have subsequently taken a range of approaches to what Dustagheer and Newman succinctly summarize as "selfconscious theatre." James Calderwood critiques the use of the prefix "meta," with its implications that metatheatricality goes "beyond drama" (4); he extends his notion of "metadrama" inward as well as outward, focussing on the "materials" and "media of language and theater, its generic forms and conventions, its relationship to truth and the social order" (5). It is precisely the "materials" of dramatic art to which I turn my attention; however, I avoid twentieth and twenty-first-century vocabularies for "selfconscious theatre," concentrating instead on how such materials and media were articulated and understood in their own period. If, as Dustagheer and Newman observe, "metatheatre of this period was qualitatively distinct," then we must pay 
attention to the discourse in which it was articulated in the period as much as to our own critical frameworks.

"Matter-theatre" therefore stands as a playful but precise historical counterpoint to Calderwood's metadrama. It allows us to move beyond metaphorical observations of dramatic self-reflexivity in the period to point to how plays are fundamentally invested in exploring their dramatic quiddity. That is to say, it points us to the materials of early modern performance — rhetorical, legal, philosophical, and technological — and to their acknowledgement by playwrights, in terms encompassed by and theorized through early modern understandings of the term "matter." "Mattertheatre" gives us one way of articulating heightened self-conscious dramatic construction in terms appropriate to a period in which it might seem that selfreferentiality is everywhere. It also moves us beyond metatheatrical moments or "events" to a more fundamental concern with dramatic construction that pervades a play: in Cymbeline, theatrical recognition and self-awareness work both theoretically — through early modern understandings of "matter"-and at the level of narrative, verse, and dramaturgy.

In Cymbeline, invocations of "matter" at key moments advertise the rhetorical "constructedness" of the play and, as we shall see, alert audiences to its various elaborate "inventions"-mechanical, rhetorical, theatrical. The term's conspicuousness points to Shakespeare's and contemporary dramatists' interest in the structures of a play and the verbal and visual devices from which it is constructed. Cymbeline brings to the fore the resonances of "matter" for early modern playgoers as a signifier of invention, imitation, and artful construction. This article goes on to explore these various meanings of matter before examining how the "materials" of dramatic art are united and signaled in Cymbeline - particularly in instances where 
stagecraft and spectacle combine with the language of "action" and where the relationship between the two is made noticeable through emblematic imagery and dumb-show-like set pieces, notably Jupiter's descent. Characters throughout Cymbeline note the complexity of plot, language, and visual spectacle, and audiences are themselves made aware of the play's constructedness through moments of patent technological artifice and rhetorical invention. Such matter-theatrical elements are particularly charged in the generically complex Cymbeline (though its mixed modes are not particularly unusual in this period): the play appears in the early years of a vogue for tragicomedy on the English stage, and while rhetorical and technological self-consciousness need not be bound to genre, they are complemented by the narrative self-reflexivity of Shakespeare's play_its ongoing tensions between repetition and recognition, expectation and consummation, delay and delight (in the play's own terms).

\section{What's the matter?}

Critics often observe that Cymbeline is theatrically self-conscious. The conventions of repetition and saturation of contrived symbolism in Shakespeare's romance have been recognized by critics as diverse as Leah S. Marcus, Raphael Lyne, and Anne Barton. Russ McDonald notes how the language and poetic style of a play is matched in its wider narrative (40). The language and style of some of Shakespeare's later plays generate a feeling of doubt that is mirrored in their overall structure, narrative, and themes. McDonald's analysis of the "patterns and fractals" in these plays shows that "they signify or function as carriers of meaning" (29). He explains that Shakespearean rhetoric in the romances often follows the pattern of the romance mode, with its "managed complexity" generating "a feeling of pleasurable 
uncertainty," eliciting anxiety and then security through the sentence structures as well as the plot structures (40). The idiosyncratic style detectable in Cymbeline also prompts a reflection on and studied consideration of language in the play. The effect is to make one aware of the contrived language and to appreciate that the "matter" of rhetoric - the stuff and subject from which an oration is made ("Rhetorique is an art to set furthe by vtteraunce of wordes, matter at large" [Wilson A1r]) — is not hidden or elided but is conspicuously present.

One can turn to the closing of Cymbeline to support this notion of bizarre syntax validating and mirroring unexpected occurrences in the narrative-especially in light of the play's questionable "happy-ever-after" ending. Jupiter tells Posthumus,

Whom best I love, I cross, to make my gift, The more delayed, delighted. (5.4.71-72)

Serving as an exquisite definition of Jacobean tragicomedy itself, Jupiter's lines omit connectives, muddy the syntax, and repeatedly delay words crucial to meaning until the second half of each phrase, after the caesura (I cross, delighted). Jupiter's words emblematize the play's own delaying of meaning and mental refreshment as it is manifested in Shakespeare's poetic and grammatical complexities, which combine with its playful and near-parodic narrative structure and its drawn out final act. The association of poetic devices or deliberate verbal artifice with wider thematic or narrative purpose can be taken further by the association of "delight" with early modern literary theory—not least in Philip Sidney's Defence of Poesie (1595), where it is used to marry pleasure to practical instruction (Defence $\mathrm{C} 1 \mathrm{v})$. The term also features in rhetorical handbooks in the period; George Puttenham, for instance, claims 
that poetry's purpose is "to refresh the mynde by the eares delight" (E1v). The tension between delay and delight is exacerbated in the Folio by Cymbeline's billing as a “Tragedy," a marker that emphasizes Jupiter's teasing delay in promising and, perhaps surprisingly, delivering the satisfaction of a "comic" ending. The earlier scenes of the play_-including its beginning in discontent ("You do not meet a man but frowns," 1.1.1) - give no certain clue to its narrative direction, and it may well be especially difficult for audiences to anticipate "delight" or dismay in these early years of King's Men tragicomedy. "Delay" is therefore a crucial word for both Cymbeline's syntax and narrative.

Stylized or ornamental language is a hallmark of early modern rhetoric, which depends upon "matter" for the subject of discourse. From its mention at the very opening of the play in the Second Gentleman's query, “what's the matter?" (1.1.3), audiences are prompted to consider the premise and the substance and construction of the play before them. The question is more than rhetorical: "matter" signifies an important stage in classical oratory. Loosely, it is synonymous with the "subject" one speaks about, as when George Puttenham talks of the "matter or subiect of Poesie" (E1v). For Thomas Wilson, the author of the most popular English manual of rhetoric in the early modern period, matter is any form of subject that enters into the discourse at hand; more precisely, the most useful matter is what should be sourced. This sourcing of relevant material is the first stage of classical rhetoric — and here Wilson borrows from his ancient forbears Quintilian, Cicero, and the anonymous and influential author of the Rhetorica ad Herennium. His list of the five key stages of oratory is as follows:

i. Inuencion of matter. 

ii. Dispocisicion of the same.
iii. Elocucion.
iv. Memorie.
v. Utteraunce.

The diagrammatic structure presented here and elsewhere in rhetorical manuals places "matter" at the heart of all rhetorical construction. Wilson states that the "finding out of apte matter" is also called "Invention," which is a "searchyng out of thynges true, or thynges likely, the whiche maie reasonably sette furth a matter, and make it appere probable" (A3v). Gathering pertinent "matter" on a subject forms the building blocks - the invention - of rhetorical construction.

Wilson's definition of "invention" as the "finding out of apte matter" hovers over the first use of the word in Cymbeline's opening scene, making the term of crucial importance to the playworld's action — both the audience and characters await the "matter" of the play. Indeed, "matter" is used to describe the content of a play and is sometimes synonymous with the performance itself. Prologues of the period marshal the term to indicate tone, type, and subject—The Two Merry Milkmaids (1619) talks of "Sence and Words, / Fitting the Matter that the Scene affords" (A4v), John Lyly's prologue to Campaspe (c. 1584) worries about offending "in matter and patience" (A3v), and Thomas Heywood's The English Traveller (c.1627) anticipates "Some Mirth, some Matter, and perhaps some Wit" (A3v). In 1582, Richard Madox shows it can be synonymous with playgoing itself: he and his companions "went to the Theatre to see a scurvy play set out all by one virgin, which there proved a freemartin without voice, so that [they] stayed not the matter" (English Professional Theatre 343). At the outset of Cymbeline, the First Gentleman's response to the 
question, "what's the matter?", therefore sets out the play's subject and contents and perhaps invites audiences to see in this exposition an indication of style, genre, or narrative (however misleading such an indication may be). "Matter" is therefore also of crucial importance to the nature and status of the fiction itself, where probability and improbability, likeliness and uncertainty are paramount. In this light, Shakespeare's continual reference to the building blocks of rhetoric indicates a selfconscious recognition of Cymbeline's artifice, engaging with questions about "truth" and moral certainty that arise from early modern Europe's fascination with rhetorical ornament. $^{2}$

The play's investment in invention is evident in King Cymbeline's own interest in matter, especially considering the term's legal applications as a subject to be tried or proved (an extension, in part, of its rhetorical significance). Cymbeline is an oddly quiet character in his eponymous play, featuring most significantly as an auditor and "audience" (as well, like the audience, as judge or jury) in the extended recognition scene (or anagnorisis) at the close, and as such his alienation from the action and his alarmed attempts to make sense of the "matter" present him as a spectator in his own play. His observations heighten the way the play's lengthy recognition scene draws attention to its status as fictional performance; these final moments extend the uncertainty or doubt generated by such scenes and in turn remind audiences of the thin line between reality and rhetoric. In the final scene, Cymbeline's urgency to "Come to the matter" and his surprise, "New matter still" $(5.5 .168,242)$, emphasise the court(room) overtones of the scene. The drama's "evidence" and "proof"- as well as its plot-is re-presented to a stage that is at once a royal court and, momentarily, a courtroom. The term signals the legal and rhetorical workings of 
moments of recognition, in which visual signs, physical tokens, and language are used and interpreted to present a compelling and plausible story.

Terence Cave explores the epistemological doubt provoked by all moments of recognition, which "reaches back most often to painful or problematic narrative events hidden in the past" and throws into doubt the signifiers that are usually associated with forms of legal proof (22). Indeed, recognition has a double sense that depends upon small, seemingly trivial identifiers but also throws such identifiers into doubt. Recognition therefore offers different ways of coming to knowledge; in "the idiosyncrasy of recognition" is "a means of knowing which is different from rational cognition," which seizes "on precisely those details that from a rational point of view seem trivial" (Cave 3). In Cymbeline, such details are at issue throughout the play as well as in this final scene. Raphael Lyne notes that in this final scene, "items of evidence are presented that, in themselves, might be deemed insufficient" (58), not least the mole by which Cymbeline identifies his long-lost son Guiderius. Given that such bodily markers are used as false evidence earlier in the play-for instance, in Iachimo's successful attempt to persuade Posthumus that he has slept with Imogenthe recognitions of the final scene are predicated upon similar potential fictions and inventions (Lyne 58). The various recognitions of this final scene-moments set up by Cymbeline's twofold amazement at narrative "matter" and his desire to come further to "the matter"- - therefore remain noticeably artificial, even as (and perhaps because) they provide such a positively satisfying resolution: "in the rhetoric of legal procedure, as of fiction, the simple or natural sign is no more independent of artifice than artifice is of signs" (Mukherji 53). The matter of these moments of closure and resolution is still the basis for the construction of probability and not unmediated truth. 
Recognition scenes, often in early modern drama and in Shakespeare's later plays in particular, present to onstage characters what audiences already know. Yet as we have seen they also ask questions about the means by which knowledge is acquired. Jan-Melissa Schramm explores how historical instances of spurious "recognition" (such as the famous case of Martin Guerre ${ }^{3}$ ) suggest that imaginative literature has an "emotional veracity" that can make artifice more truthful than anything else: it is "the power of poesy to generate the most effective and 'truthful' anagnorisis" (201). For Schramm, recognition scenes therefore elicit an anxiety on behalf of beholders, readers, or viewers that "imposture" might be dangerously plausible even if it is "evidently parodic and weakly imitative" (201). That is, we are drawn to believe in spite of the patent inadequacy of imposture. The "matters" of Cymbeline's final act advertise their legal-rhetorical jargon, replay the lengthy oratorical persuasions that form earlier deceptions, and delay information and answers. In so doing, the play exposes the verbal devices and unreliable tokens that create plausibility and persuasion and threatens to unveil the whole fiction itself as a "parodic and weakly imitative" imposture (Schramm 201) at the same time as it encourages our delight in the fiction. Cymbeline also borrows narrative tropes and characters familiar from earlier early modern plays and Shakespearean plots - the “monstrous" Queen, star-crossed lovers, a weak king, Roman wars, early "Britain," a cross-dressing heroine, a banished courtier, and so forth—-populating together an unlikely playworld (an echo, perhaps, of George Peele's romance-trope-bingo play, The Old Wife's Tale [c.1592]). The familiarity of each element of the dramatic story heightens the sense that the play is a parodic imitation. Indeed, Schramm's phrase comes close to Cymbeline's own acknowledgement in the play's final two lines that "Never was a war did cease, / Ere bloody hands were washed, with such a peace" 
(emphasis added, 5.5.482-83). While audiences, like the King, might be drawn to believe, Cymbeline continually reminds us that the whole fiction is but an imposture — often an unlikely one. This tension between belief and disbelief prompts a metatheatrical awareness of the play as a fictional construct and works by distancing audiences while simultaneously drawing them in. The legal and rhetorical aspects of recognition in the final act spark an awareness of structure and story that precipitates a re-cognition of the play's "matters."

These recognition moments are complemented by the play's foregrounded rhetorical constructions and interpretations. Cymbeline's urging of Iachimo to come "to the matter" and "to th' purpose" $(5.4 .169,178)$ prompts another lengthy speech from Iachimo that more or less repeats his rhetorical performance in Imogen's bedchamber and the persuasive speeches that falsely win the wager with Posthumus. Iachimo's simple acknowledgement that all was "simular proof" is again only a verbal admission, and again it prompts immediately heated belief from the impulsive and ever-credulous Posthumus. When in his fury Posthumus then strikes the disguised Imogen, he cries, "Shall's have a play of this?" (5.5.228). His line urges nobody to trivialize the moment, but it also draws attention to the fact that Iachimo's speech is indeed the very matter of the play audiences have just watched: the artifice of language is the essence of the drama.

\section{Speaking, sense, and action}

Rhetorical construction and physical evidence conjoin in wider connotations of the word "matter." The rhetorical conception of "matter" draws on Aristotelian definitions, which are widely understood throughout the medieval and early modern periods. For Aristotle and his numerous followers, syncretizers, and borrowers, 
"matter" forms the building blocks of physical objects in the world, just as it forms the building blocks of an oration in rhetoric. "Substance"- the primary, most basic state of physical existence — is the jointure of "matter" with "form." An analogy: matter is the wax, the "form" is the impression (i.e., of a house); when combined, they generate the substance of a house. ${ }^{4}$

Aristotelian "matter," then, is physical—by its very etymological association, it is "material." The verbal or mental meanings of the term to the rhetorician Wilson are effectively "material" metaphors; although more hidden, they bear the traces of the early modern and medieval predilection for conceptualizing the abstract in terms of the physical world (seen in practical visualizations of memory as a house or a theater).

The combination of matter with physical craft is also seen in feats of technology in the Jacobean period. Cornelius Drebbel's perpetual motion machine (unveiled at James's court in 1607) is described in Thomas Tymme's pamphlet, $A$ Dialogue Philosophicall (1612). The dialogue concerns how motion is derived from matter and form, and Drebbel's creation of his machine is described in terms of the manipulation of matter: "Cornelius [. . .] extracted a fierie spirit, out of the mineral matter, ioyning the same with his proper Aire [. . .]" (I3v). In Tymme's dialogue, matter combines the metaphor of the "workman"-a God-like creature who can mold essentials and elements—with its literal, mundane, workaday meaning: one who creates and crafts objects. Mineral matter is linked with wheels and axels, and the notion of "matter" as a building block is literalized. Drebbel's perpetual motion machine offers an alternative meaning to the "invention of matter." Wilson's rhetorical notion of true or likely "thinges" is, in Tymme's pamphlet, composed of physical, external "things." Even the term "invention" has its associations with 
mechanical technology in texts such as William Bourne's Inuentions or deuises (1590), the title of which captures the close relationship between physical and verbal creation.

The physical associations of "matter" are extended in the sixteenth and seventeenth centuries when it begins to find currency not only in terms of scholastic philosophy but as part of anatomical discourse. Crooke describes the body as being "made of sublunary and elementary matter"—a condition that he claims enables sensory knowledge (B3v). Corporeality itself is described throughout his anatomical work as a condition of "matter": "For the matter of mans body, it is soft, pliable and temperate, readie to follow the Workeman in euery thing, and to euery purpose ..." (B3r). While matter clearly retains its Aristotelian connotations, it begins to signify by itself an "object" or corporeal "thing" in the physical world. The familiar metaphor of the workman suggests God's own molding of matter and his creation of substances, but it also associates the term with craft and with flesh and physicality. In the late 1600s and early 1610s, then, "matter" (and, indeed, "invention") has both rhetorical and physical associations. ${ }^{5}$

The physical, material, and scientific associations of "matter" draw attention to the links between Shakespeare's rhetorical style and Cymbeline's stagecraft. Early modern rhetoric itself begins to bridge the gap between physical and verbal action throughout the Elizabethan era and into early Jacobean England. Cymbeline represents those changes by materializing its language in spectacle. Jupiter's bizarre deus ex machina entry and his spoken judgment on the action illustrate a particularly acute moment of shared rhetorical and visual matter at work. Shakespeare makes rhetorical "effects" synonymous with action in the "material" world through a riddle and through Posthumus's confused response to the tablet Jupiter has given him: 
'Tis still a dream, or else such stuff as madmen

Tongue and brain not; either both, or nothing,

Or senseless speaking, or a speaking such

As sense cannot untie. Be what it is,

The action of my life is like it, which I'll keep,

If but for sympathy. (5.4.115-20)

Despite acknowledging that he does not understand the tablet and that it may be distracted speech, Posthumus is nonetheless happy to accept that the "Action" of his life (capitalised in the Folio, Bbb3v) — and indeed the play generally_is "like it." Here, the riddle proves quite the opposite of "senseless speaking" and suggests rather that speech is intimately bound up with sense and sensory effects.

Posthumus's recognition that the "Action" of his life is like the words speaks to the growing emphasis on "action" as a physical extension and embodiment of speech in early seventeenth-century rhetoric, notably in Thomas Wright's expanded The Passions of the Mind (1604); Keir Elam sees in Wright's text, for instance, a shift towards situating passionate expression on "the borderline between elocutio in its schematic guise and actio, performance" (72). This physicalization is captured in particular in Cymbeline's dumb-show-like moments. Marion Lomax recognizes the parallels between the deliberately archaic form of a dumb show and Jupiter's entry in Cymbeline, calling the scene with Jupiter and the succession of ghosts "a silent, dream-like sequence, befitting the spirit of the play as a whole" (31). Such instances in early modern drama insist on a mutual relationship between speech and visual action, and Jeremy Lopez identifies this relationship at the level of interpretation: 
Watching a dumb show, you must not only work vigorously to interpret gestures [...] you must also put the act of interpretation into a kind of suspense, waiting for later action, accompanied by words, to help you sort out meanings [. . .]. (294)

Dumb shows and dumb-show-like moments align the matter of rhetorical delivery with physical motions. Wright's expanded Passions of the Mind makes this association explicit. For Wright, dumb shows in particular are closely related to rhetorical matter:

The internall conceits and affections of our minds, are not only expressed with words, but also declared with actions: as it appeareth in Comedies, where dumbe shewes often expresse the whole matter ...." (I6v)

Expressing "the whole matter" explicitly combines the term's rhetorical connotations with its corporeal sense. Wright advises orators to frame their physical action to the words, something that Keir Elam sees as essential to acting on the early modern stage: the actor literally "gives body to discourse through the corporeal orchestration of speech" (75). As such, the rhetorical uniqueness, metrical ruggedness, and syntactic circuitousness of Shakespeare's romances have their duplicate in body.

Wright hopes that good oratorical delivery "may effectuate strange matters in the mindes of his Auditors" (B2r). The association with "matter" draws on both physical and verbal aspects of oratory, making matter both the content of the oration and its physical and mental effects in the mind. He stresses that with the rules of action allied to pronunciation, "how much more liuely it representeth the conceits and 
affections of the mind, because that thorow both the eares and the eyes of their auditors, they intend to imprint them in their soules the deeper" (I6v). Wright's rhetoric is explained in explicitly visual and physical terms, from "imprinting" to effectuating matter. Cymbeline literalizes such a conception of stylized or ornamental language by associating spectacle with rhetorical delivery in its various possible meanings. The uniting of language and action feeds into Cymbeline's selfconsciousness, exposing the "matter" in each aspect of the play's construction and performance. Indeed, this pervasive metatheatricality is particularly conspicuous at moments, discussed in the final section, where the play's stagecraft advertises the manufacture of its verse, visual spectacle, and narrative. At the same time, the combined theatrical "matter" of Cymbeline keeps audiences aware of the allencompassing artifice of the play.

\section{A book?}

Jupiter's riddle falls under what Tiffany Stern has labeled "scrolls"__"papers that are to be delivered onstage" (174). Upon his arrival, announced by a stage direction in the Folio, Jupiter delivers a lengthy speech that includes significant deictic language: “This Tablet lay vpon his Brest, wherein / Our pleasure, his full Fortune, doth confine" $(F$. bbb3v; 5.4.79-80). In modern editions, this is often glossed with a stage direction like that in Norton 3: "He gives the ghosts a tablet which they lay upon Posthumus' breast' (5.4.80.1-2). Stern suggests that the preserved feature of the scroll in a printed text reflects the way the stage prop itself would look, its appearance in print making it a "would-be stage property and sometimes a preserved one" (179). As a focal point for the spectacular entrance and oration of Jupiter, a physical version of the scroll—or book, or tablet, or however the prop might look in 
any given performance - is a central part of the scene's stagecraft. In descending, delivering an oration, and very literally delivering “words," Jupiter's entry draws verbal modes into line with "Action." The physicalised delivery of words in such a spectacular manner also exposes the agencies and materials that underlie dramatic creation-authoring the play, writing the manuscript parts, and putting them into action on the stage. As such, Jupiter's deus ex machina is inherently matter-theatrical, as it becomes representative of the "matter" integral to performance, a point expanded on below.

Posthumus immediately draws a connection between rhetorical and physical or narrative effects. Upon waking, he notes

A book? O rare one,

Be not, as is our fangled world, a garment

Nobler than that it covers. Let thy effects

So follow to be most unlike our courtiers,

As good as promise. (5.4.103-07)

Posthumus tries not to judge a book by its cover, and his remark alludes to early modern concerns with ornamental rhetoric and the perceived growth of style over substance. Francis Bacon criticizes the prioritization of style in The Advancement of Learning (1605). He gives a succinct analysis of sixteenth-century rhetoric and the growth of "eloquence and varietie of discourse":

. . these foure causes concurring, admiration of ancient Authors, the hate of the Schoole-men, the exact studie of Languages: and the efficacie of Preaching 
did bring in an affectionate studie of eloquence, and copie of speech, which then began to flourish. This grew speedily to an excesse: for men began to hunt more after wordes, than matter [...]. (E3r) ${ }^{6}$

Bacon echoes Posthumus's concern with the "effects" of speech and the content underlying them — the "promise" of words and the actual outcome. Bacon's discussion of eloquence also chimes with Cymbeline's wider exploration of the relationship between words and, to paraphrase King Cymbeline, amazing matter: Bacon worries about writers who have more interest in "the choiseness of the Phrase . .. and the varying and illustration of their workes with tropes and figures then after the weight of matter [ . . ]" (E3r-v). These concerns are brought to the fore in Cymbeline through Shakespeare's convoluted syntax and verbal style and characters' simultaneous interest in the narrative "matter" of the play. Everybody, including the gentlemen at the opening and Cymbeline during the recognition scene, is concerned with pointing out the oddity of their situation, the implausibility of the narrative, and the opacity of the play's prolix language.

Jupiter's entry in Cymbeline therefore encompasses Wright's model of combined "action" in the play, uniting concern with the effects and meaning of words with their physicalization through a prop and its spectacular delivery. It also alerts audiences to the "matter" of words and spectacle in a physical sense-with the materiality of performance. Jupiter's "descent" draws attention to the writing, making, and delivery of words; to pulleys and flight machinery underpinning such spectacular moments; and to movements between on and "off" stage worlds. It therefore points to the various agencies involved in dramatic creation both inside and, picking up on the Greek etymology of "meta," "beyond" the fictional playworld: the actors, 
playwrights, and stage hands who blur in Cymbeline any such distinctions between the play and the playhouse. Their creativity is celebrated in the play's insistent display of artifice, and this deus ex machina represents not only Jupiter (or his symbolic resonances in early Jacobean England) but the creative labors that bring visual and verbal effects into being.

Cymbeline's conjunction of "Action” and speech also aligns with wider associations between reading and the physical world in the early modern emblem tradition. The book or scroll delivered by Jupiter is claimed to be of great weight and importance, including the revelation of Posthumus's "full fortune." The rhetorical device in the scroll-riddle essentially promises cryptic access — through a speaking that sense "cannot untie" - to the book of nature and divine providence. As such, the rhetorical qualities of Jupiter's descent become even more apparent. Michael Bath explains the connection between rhetoric, nature, and meaning in the emblem tradition:

the emblem was conceived both as an art of rhetorical invention [...] and at the same time as an art which used inherent meanings already inscribed in the Book of Nature by the finger of God. (3)

Henry Peacham's Minerua Britanna (1612) includes an emblem that makes precisely those associations explicit (see Figure 1). Though perhaps a coincidence, the collection was printed a few years after Cymbeline was first performed (and a year after its performance at court) and its symbolism fits the scene of Jupiter's descent perfectly. 


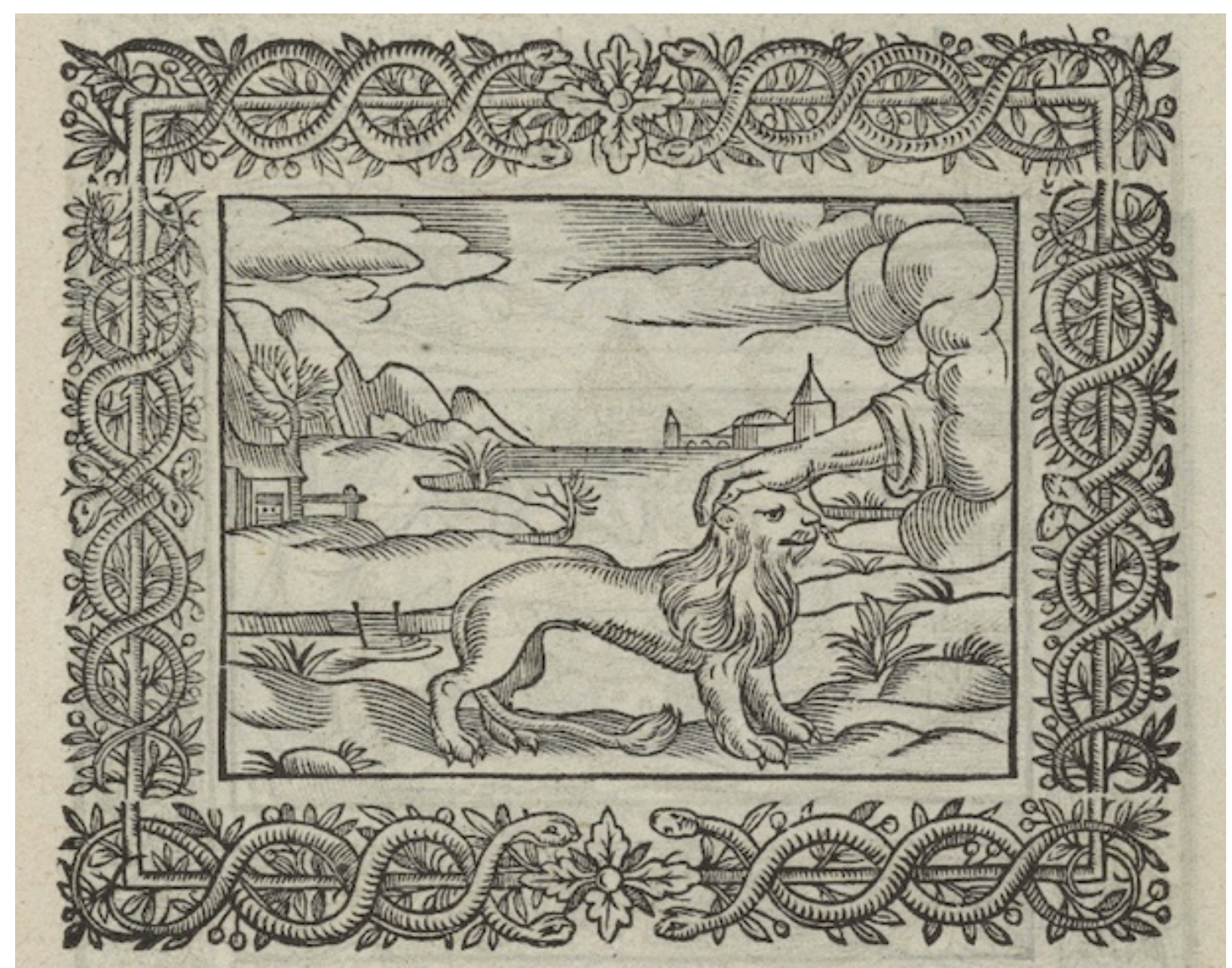

Figure 1. "Poulatim" from Peacham's Minerva Britanna (London, 1612; N4r). STC 19511 Copy 1 (Digital Image File 66939). Used by permission of the Folger Shakespeare Library under a Creative Commons Attributino-ShareAlike 4.0 International License.

The emblem warns reader-viewers not to resist fate:

By violence who tries to turne away,

Strong natures current, from the proper course,

To mooue the Earth, he better were assay,

Or wrest from Ioue, his thunderbolts perforce [. . .]. (N4r)

Jupiter's delivery of a rhetorical riddle, or emblem, suggests that divine rhetoric allies with matter to construct the "proper course" of the play, and Posthumus correctly reads its as predicting or aligned with the "Action" of his life. The lion in Peacham's 
image conveniently links Jove with Shakespeare's Posthumus Leonatus. Peacham was a known playgoer who drew a sketch of a performance of Shakespeare's Titus Andronicus, making it perfectly possible that Peacham drew inspiration for this emblem from a performance of Cymbeline. Yet even ignoring such conjecture, the extraordinary similarity in structure and composition indicates Shakespeare's dramaturgical investment in the visual-verbal representation of the emblem tradition — a stage practice, Jerzy Limon shows, commonly incorporated into courtly masque performance (86-91).

The delivery of the book itself marries the expressive "dumb show" quality of Jupiter's descent with his stylized speech through the visual effects of thunder and lightning (likely a cannonball and pyrotechnic effect):

Jupiter descends in thunder and lightning, sitting upon an eagle. He throws a thunderbolt. The ghosts fall on their knees. (5.4.64.1-3)

The visual symbolism detailed in this stage direction aligns the figure of a god with the figures of rhetoric, especially amplificatio, in which orators "breaketh all in peeces, like a thunderbolt" (Peacham N2v) — a device at the center of the period's moral anxieties over rhetoric. ${ }^{7}$ Amplification is employed at this moment in Cymbeline in order to heighten the power of the spectacle: "a certain affirmation very great \& weighty, which by large \& plentifull speech, moueth the minds of the hearers, \& maketh them to beleeue that which is said" (Peacham N2r). Wilson also views amplification in visual-aural terms, noting that "Uehemencie of words full often helpe the matter forwarde [...] than if the thing had been spoken in plaine words. When wee heare one say [. . .] The Preacher thundered in the Pulpite [...]" (S2v). 
"Uehemencie" and use of non-plain words begin to echo the material effects that Wilson and Puttenham desire in a good oration.

The use of amplification in Jupiter's own speech is somewhat ironic, even paradoxical. He offers triple-confirmation of his power in ending Posthumus's trouble-_[Posthumus] our godhead will uplift; His comforts thrive, his trials well are spent" (11.73-74) — in line with Wilson's summary that "Amplifying of the matter, consisteth in heaping, and enlarging of those places, whiche serue for confirmacion of a matter" (q4r). The vagueness of his prophetic deliverance sends up the very ends of amplification — to persuade and cause belief - yet in spite of its imprecision, Jupiter's words serve, as we have seen, in convincing Posthumus of the tablet's significance. In this sense, Jupiter's rhetoric represents a divine form of rhetorical device that, like emblems or the natural world, must be interpreted to be understood. Jupiter's set piece is doubly effective, though, as a verbal and visual device. As a metaphor for vehement speech, thundering is made quite literal in Cymbeline through its use as a visual-aural prop: Jupiter's rhetorical style becomes a special effect. Certainly, the languageJupiter's, the tablet's, Posthumus's — is decidedly removed from "plaine words" (as Posthumus makes clear in his comment about its "sense"), effectively making the deity's descent a combination of rhetorical and physical devices that very literally "helpe the matter" of the play forward.

The physical matter of Jupiter's entrance may also be conspicuous in the playhouse. Just as Shakespeare's rhetorical style draws attention to itself through its contrived complexity and through references to rhetorical terms like "matter," underlying physical "matter" is likely detectable in the stagecraft. Like Jonson's contemptuous reference to the "creaking throne" coming from the heavens (Every Man In A3r), Jupiter's entrance has the potential to alert audiences to the play's 
physical constructedness. Thomas Campion's Masque of Squires, performed in 1613, did not impress the Agent of Savoy, who wrote back to Spain that the mechanics of the stage effects were all too noticeable: "one could see the ropes that supported it [the "cloud"] and hear the pulleys or rather wheels, making the same noise as when they raise or lower the mast of a ship" (trans. Orrell 304): the "matter" of the spectacle was laid bare. An elaborate entrance on an eagle at the Globe and especially in the smaller Blackfriars playhouse would no doubt advertise some of its own workings in the same way that Shakespeare draws our attention to the workings of verse. The ghost Sicilius refers audiences to the materials of visual special effects by remarking after Jupiter's exit, "He came in thunder, his celestial breath / Was sulphurous to smell" (5.4.84-85). Sicilius refers to the perceived odor of thunder and lightning, but also to the "sulphurous" smell of special effects such as squibs in the playhouse. ${ }^{8}$ It is telling that they are aligned with Jupiter's “celestial breath," further connecting the sensory experience of his elaborate entrance with the effects of his speech; the ghost's remark therefore underscores the relationship between the thundering device of amplification and the thundering effects in the playhouse, drawing audience attention to both.

When Jupiter's riddle is read for the second time shortly after his departure, 9 Posthumus encourages the Soothsayer to interpret it: "Let him shew / His skill in the construction" (5.5.431-32). The final instance of interpretation is framed as an act of "making," following the play's preoccupations with creating material things from language. "Construction" refers, as it is usually glossed, to the Soothsayer's interpretation, but it draws on geometric uses of the term to describe a figure drawn to solve a problem. ${ }^{10}$ It therefore calls to mind the manufacture of the riddle itself: its rhetorical "matter." Being read out for a second time, the prop/riddle takes an 
audience back to the text's delivery, a moment of conspicuously constructed stagecraft that draws attention to the invention of its verbal as well as its visual devices. It is a creation that mirrors the playwright's own making, whose profession is described by the very word playwright as a craft (Stern 1), one that insists on the wider technological, practical, and hence material aspects of theatrical production. Even in the play's final moments of de-construction —-when all should be interpreted-Cymbeline reminds us of the nature of all of its visual and verbal matters: they are "constructions." The words also serve as a gloss on the playwright and stagehands themselves: they have shown us their skill in the construction.

Early seventeenth-century audiences are continually reminded of Cymbeline's rhetorical and technological constructions by explicit references to "matter" and through moments that gesture to the inventions underlying stylised speech and spectacular effects. The play continually points to its narrative oddity, and its plot structure is mirrored in its linguistic features. Both the narrative and the verse are invested in delaying delight, and characters' reference to these qualities alert us to the nature of the play as theatrical invention. Indeed, invention, imitation, and parody are at the heart of its interdramatic allusions and its exploration of knowledge and truth in the closing moments of recognition.

Opening with the question, "what's the matter?", Cymbeline tells audiences it is interested in exploring the nature of dramatic representation. "Matter-theatre" offers an early modern alternative to the twentieth-century critical term "metatheatre"; it makes conspicuous the play's inventions, fictions, and constructions. Cymbeline is particularly self-reflexive as a play, perhaps in part due to its relationship with the narrative self-consciousness of tragicomedy in the early decades of the seventeenth- 
century. Yet "matter-theatricality" is pertinent to and present in the many plays in late sixteenth- and early seventeenth-century England that advertise the technology, narrative, and language - the various matters - of their performances.

\footnotetext{
Notes

${ }^{1}$ Unless indicated otherwise, all references are taken from The Norton Shakespeare, third edition. Other iterations of the question occur at 1.6.46 (in a first act characterized by questions), 3.4.10, 3.6.41, 4.2 .191 (where it is given as simply, "The matter?").

${ }^{2}$ Several studies have shown how methods of teaching in the humanist curriculum and associated rhetorical practices are seen to exaggerate truths, cover lies, and situate facts as up for debate. Markku Peltonen explores grammar school practices, where "virtues were taught as part of eloquence"; speaking in utramque partem (on both sides of an issue) added to the sense that every matter was up for deate $(163,172)$. Quentin Skinner also explains how Elizabethan and early Jacobean emphases on figures, tropes, and ornamental rhetoric can sometimes serve to present facts in "a different moral light" (145).

${ }^{3}$ See Natalie Zemon Davis's influential discussion of this case in The Return of Martin Guerre (1983).

${ }^{4}$ Aristotelian matter is endlessly recycled into various different substances by combining with different forms.

"For more on the rhetorical and physical associations of "invention," see Davies, "Seeing Speech as Spectacle in The White Devil."

${ }^{6}$ Bacon associates the importance of persuasive and attractive language with the labour of "winning" the people to Protestantism and associated beliefs in postLutheran Europe.

${ }^{7}$ Skinner explains that amplification is used in the English Renaissance "to cover the whole process of arousing the emotions by way of stretching the truth" (136).

${ }^{8}$ Ben Jonson's The Devil is an Ass (1615) makes a similar reference to the stench of "squibs" or fireworks: "MER. Peace, good squib, goe out. / CRI. And stinke, he bids you" (X1v).

${ }^{9}$ The riddle is the only text in Shakespeare's corpus read, aloud and uninterrupted, more than once (Smith 32).

${ }^{10}$ See Henry Billingsley's translation of Euclid's The elements of geometrie (1570) (C4r-v).
} 


\section{Works Cited}

Abel, Lionel. Metatheatre: a new view of dramatic form. Hill \& Wang, 1963.

Acheson, Katherine. Visual Rhetoric and Early Modern English Literature. Ashgate, 2013.

Altman, Joel. The Tudor Play of Mind: Rhetorical Inquiry and the Development of Elizabethan Drama. U California P, 1978.

Bacon, Francis. The tvvoo books of Francis Bacon. Of the proficience and aduancement of learning, diuine and humane. London, 1605. Early English Books Online. Web. 20 June 2017.

Barton, Ann. Essays, Mainly Shakespearean. Cambridge UP, 1994.

Bath, Michael. Speaking Pictures: English Emblem Books and Renaissance Culture. Longman, 1994.

Bourne, William. Inuentions or deuises... London, 1590. Early English Books Online. Web. 20 June 2017.

Cave, Terence. Recognitions: A Study in Poetics. Clarendon, 1988.

Crooke, Helkiah. Mikrokosmographia. London, 1615. Print.

Davies, Callan. "Seeing Speech as Spectacle in The White Devil." Literature Compass 13.9 (2016): 548-59.

Davis, Natalie Zemon. The Return of Martin Guerre. Cambridge MA and Harvard UP, 1983.

Devereux S. J., James A. "The Meaning of Delight in Sidney's Defence of Poesy." Studies in the Literary Imagination, volume 15, number 1, 1982, pp. 85-97.

Elam, Keir. "Early Modern Syntax and Late Shakespearean Rhetoric.” Early Modern English: Trends, Forms, Texts, edited by C Nocera Avila, N. Pantaleo, and D. Pizzini. Schena Editore, 1992, pp.63-80. 
English Professional Theatre 1530-1660. Eds Glynne Wickham, Herbert Berry, and

William Ingram. Cambridge UP, 2000.

Euclid. The elements of geometrie of the most auncient philosopher Euclide of Megara. Trans. Henry Billingsley. London, 1570. Early English Books Online. Web. 15 Sep. 2015.

Heffernan, James A. W. "Ekphrasis and Representation.” New Literary History 22.2 (1991): 297-316. JSTOR. Web. 20 June 2017.

Heywood, Thomas. The English Traveller. London, 1633. Early English Books Online. 31 Aug. 2017.

Jonson, Ben. The divell is an asse. London, 1641. Early English Books Online. Web. 20 June 2017.

---. Every Man In His Humour. The workes of Beniamin Ionson. London, 1616. A2rF7r. Early English Books Online. Web. 31 Aug. 2017.

Limon, Jerzy. The Masque of Stuart Culture. U of Delaware P, 1990.

Lomax, Marion. Stage Images and Traditions: Shakespeare to Ford. Cambridge UP, 1987.

Lyly, John. Campaspe. London, 1584. Early English Books Online. 31 Aug. 2017.

Lyne, Raphael. "Recognition in Cymbeline.” Late Shakespeare, 1608-1613. Eds

Andrew J. Power and Rory Loughnane. Cambridge UP, 2013. 56-70.

---. Shakespeare's Late Work. Oxford UP, 2007.

McDonald, Russ. Shakespeare’s Late Style. Cambridge UP, 2006.

Marcus, Leah. Puzzling Shakespeare: Local Reading and its Discontents. U of

California P, 1988.

Mukherji, Subha. Law and Representation in Early Modern Drama. Cambridge UP, 2006. 
Ong, Walter. Ramus, Method, and the Decay of Dialogue. 1958. Harvard UP, 1983.

Orrell, John. "The Agent of Savoy at The Somerset Masque." RES 28 (1977): 301-04.

Print.

Peacham, Henry. Minerua Britanna. London, 1612. Early English Books Online.

Web. 20 June 2017.

Peltonen, Markku. "Virtues in Elizabethan and Early Stuart Grammar Schools."

Journal of Medieval and Early Modern Studies 42.1 (2012): 157-179. Print.

Puttenham, George. The Arte of English Poesie. London, 1589. Early English Books Online. Web. 20 June 2017.

Schramm, Jan-Melissa. Atonement and Self-Sacrifice in Nineteenth-Century Narrative. Cambridge UP, 2012.

Shakespeare, William. Cymbeline. Mr VVilliam Shakespeares Comedies, Histories, \& Tragedies. Published according to the True Originall Copies. London, 1623. Zz3rbbb6r. Early English Books Online. Web. 20 June 2017.

---. Cymbeline. Ed. Ann Thompson. The Norton Shakespeare. Ed. Stephen Greenblatt et al. Norton, 2016. 3025-3119.

---. Hamlet. Ed. Anthony B. Dawson. The Norton Shakespeare, edited by Stephen

Greenblatt et al. Norton, 2016, pp. 1751-1853.

Sidney, Philip. Defence of poesie. London, 1595. Early English Books Online. 31 Aug. 2017.

Skinner, Quentin. Reason and Rhetoric in the Philosophy of Hobbes. Cambridge UP, 1996.

Smith, Warren D. Shakespeare's Playhouse Practice. UP of New England, 1975.

Stern, Tiffany. Documents of Performance in Early Modern England. Cambridge UP, 2009. 
Turner, Henry S. The English Renaissance Stage: Geometry, Poetics, and the Practical Spatial Arts, 1580-1630. Oxford UP, 2006.

The two merry milke-maids. London, 1620. Early English Books Online. Web. 16 Sep. 2015.

Tymme, Thomas. A dialogue philosophicall. London, 1612. Early English Books Online. Web. 20 June 2017.

Wilson, Thomas. The arte of rhetorique for the vse of all suche as are studious of eloquence, sette forth in English. London, 1553. Early English Books Online. Web. 20 June 2017.

Wright, Thomas. The passions of the minde in general. London, 1604. Early English Books Online. Web. 20 June 2017. 